\title{
Indigenous population in the cities: visibility and ethno-political organization in the metropolitan area of Buenos Aires, Argentina
}

\begin{abstract}
In the last two decades, the indigenous population of Argentina configured spaces of participation and ethno-political organization. This process was accompanied by the legal recognition of the indigenous population in the 1994 year, which it had impacted on the indigenous socio-cultural organization and the reorientation of the negotiation modalities and participation inside and outside the state structures. The objective of this study is to analyze a recently demographic data to show that migration process of indigenous population to the Metropolitan Area of Buenos Aires mainly since the 1960s shows an important presence of indigenous in the city; and how those families has constituted themselves as political actors in the last two decades. Secondly and in an approximate way, we will present information that allows us to argue that the presence of urban indigenous in the province of Buenos Aires is not a new phenomenon. That fact is relevant because there are different conceptions that assume indigenous people only as part of the rural contexts and away from the urban and peri-urban spaces. So we will present the analysis of "urban indigenous" from an approach that first points to their heterogeneity and secondly to highlight the relevance that intercultural relations have had when we analyze the contemporary ethno-political and urban organization.
\end{abstract}

Keywords: urban indigenous, ethno-political organization, cities, state, public policies
Volume 3 Issue I - 2018

\author{
Engelman Juan Manuel \\ Universidad de Buenos Aires, Argentina
}

Correspondence: Engelman Juan Manuel, Facultad de Filosofía y Letras, Universidad de Buenos Aires, Argentina,

Email jmengelman@hotmail.com

Received: August 25, 2017| Published: January 16, 2018

\section{Introduction}

Before we began to the development of the work, it is necessary to clear out two aspects that contribute to introduce the theme and also to avoid a possible misreading of the "urban indigenous" notion. Firstly, when we speak of "urban indigenous people" we refer to the migrated, located and or born population in the cities. The disparity of histories, migratory trajectories and identities means to us a social composition highly differentiated in the Metropolitan Area of Buenos Aires (AMBA), the Autonomous City of Buenos Aires (CABA) and other urban agglomerations of Argentina. In this sense, the present work does not specifically refer to the analysis of an ethnic group or a particular case; instead of that, we highlight the importance of the systematization and comparison of the heterogeneous experiences and actors involved.

On the other hand, the degree of differentiation within indigenous communities or nucleation's ${ }^{1}$ increases if we consider variables such as age or gender. Although both aspects are not part of the present inquiry, we understand their importance to analyze the complexity composition of the ethnographic field. Secondly, we emphasize the negative character that, from common sense, assumes the notion of "indigenous" when it is adjectivized by the word "urban". According to that, urbanity understood as the material condition for cultural reproduction has a denying effect because organized (locates) the indigenous population opposite to modern spaces (rural).

1For Liliana Tamagno, ${ }^{2}$ the notion of "nucleation" refers to the migratory process of the indigenous population and their ability to nucleate - as far as material conditions permit - in geographical spaces different from those of origin. $^{2}$ The relational and historical character of the notion is in line with a position that dynamizes and criticizes the culturalist sense of the category of "indigenous community" and hence its relevance.
This movement or primary perception has a double stigmatizing effect because it contributes to the segmentation of the indigenous population under the aforementioned geographical criterion and secondly because the "veracity" of ethnic identity is questioned by the apparent transformative effect that modern space has on its natural "traditionalism". ${ }^{1}$

Therefore, this essential character of denying/invisibilizing becomes important to understand, on one hand, the daily dynamics of indigenous families and their political leadership formation process on the other. It is important to clarify that these images have also delineated the research process and the construction of the object of knowledge according to a constant reformulation of the questions, from the beginning of the ethnographic work to the present time. The reflections here are the product of the ethnographic work made it between the 2008 and 2017 years in different AMBA municipalities such as Almirante Brown, Moreno, Marcos Paz and Quilmes. During this period, we used the participant observation, closed and open interviews with indigenous referents, state officials and local members, provincial and national social groups and organizations.

\section{Indigenous presence in the metropolitan area of Buenos Aires (AMBA)}

According to the data published by the National Institute of Statistics and Censuses (INDEC), in 2015 we can say that the amount of indigenous population in Argentina is concentrated mainly in urban areas. The national indigenous population descends or selfrecognized is about 955,032 habitants. Of that total number, $81.9 \%$ $(782,171)$ live in urban areas, while the remaining $19.1 \%(172,861)$ live in the rural ones. If from that $81.9 \%$-which represents the total 
of urban indigenous of the country we discriminate those who live in the Metropolitan Region we will see that the $31 \%$ of the "urban Indians" $(248,516)$ have migrated or were born in that area. So, eight of ten Argentinean's indigenous live in cities and three of them are living in the Autonomous City of Buenos Aires (CABA) or in the AMBA. ${ }^{3}$ It is worth to mention that this situation is not unique in our country, because it is replicated in different Latin American cities. Clearly, indigenous populations migrate to spaces where the formal and informal labor market, especially in the sector of services, is not only assumed by the migrants as a permeable space to find work but also is where it is concentrated. Nevertheless, the displacement of the indigenous population or the composition of the urban indigenous population should not be restricted to national boundaries. The case that will be discussed below exemplifies that the indigenous population of the AMBA it's constituted in part by the migration of families from other countries such as Paraguay, Bolivia or Peru. In that case regionality must be the methodological criteria of analysis and not the boundaries of each nation in order to rethink the presence of indigenous people in the cities as well as it's heterogeneity. Although we consider the latter as a relevant part for analyze that surrounds the complexity of the "indigenous people", we must emphasize that its organization express a reconfiguration of their ethnicity in the urban contexts. We cannot think that these cultures as a past "survivors", or as an unchanged of times expression. In the majority of them, have operated processes of ethnic and cultural transfiguration involving the reconfiguration of existing matrices or cultural forms, until developing new social configurations that remember that past, but not represent their present. ${ }^{4}$ This transfiguration has been and its, the basic mechanism for the identity reproduction in where different cultural signification can be assumed. This is possible because cultures can change but the alternative social fields remain. ${ }^{4}$ However, it should be noted that the brief presentation of statistical data refers only to a sector of the indigenous population surveyed. The differences between estimations and census studies ${ }^{5}$ becomes when we are preparing a certain quantitative evaluation, an essential tool. According to Alejandro Balazote, every time where the indigenous people where measurement by the State of Argentina there was an underlying motive. The first demographic surveys were carried out during the campaigns of conquest in the 19th century and their objective was to know the military information of the indigenous population. Subsequent measurements of the 1960s were important to assess their legal status. Thus, we question ourselves about the underlying motives behind recent estimates given that "in the last census, the use of the self-ascription criterion made it possible to note socio-cultural characteristics". ${ }^{6}$

\section{The indigenous population of the amba}

The AMBA region is composed by different localities and neighborhoods of the Autonomous City of Buenos Aires and the Greater Buenos Aires (Figure 1). The 30\% of the total population of Argentina it's concentrated in this geographical extension. ${ }^{3}$ The spatial distribution is defined by the delimitation of 33 municipalities, grouped in eight different zones: Southeast, La Plata, South, Southwest, Northeast, Northwest, North Center and West. In addition of each jurisdiction, the extension of the AMBA is divided into three peri-urban cords that surround the Autonomous City of Buenos Aires (Figure 1)

The present's reflections were the result of the ethnographic work carried out with the indigenous population located in the second and third cordon of the AMBA and specifically in the south, northeast and west region. To introduce the main ideas of this work, we will mention four aspects that we believe are relevant to understand the processes of ethno-political organization, according to emphasize the importance of the historical approach in the studies of indigenous presence in the cities. In the first place, several authors agree that the 1960s marked the beginning of an internal migration process where large social sectors and indigenous families began to settle in the periphery of the Autonomous City of Buenos Aires and the AMBA..$^{7-9}$ In a recent study, we emphasized that the indigenous population arrived to the province of Buenos Aires as part of social migrant contingents that arrived in the city looking for an improvement of their living conditions, better access to works, health and education circuits. Although the indigenous population represented a smaller number of migrants -in relation to the high density of population already located in the AMBA- they participated in the process of urbanization of the city and their spatial distribution, at the same time, expose the importance of the kinship relationships and interethnic alliance from their origin places. ${ }^{1}$

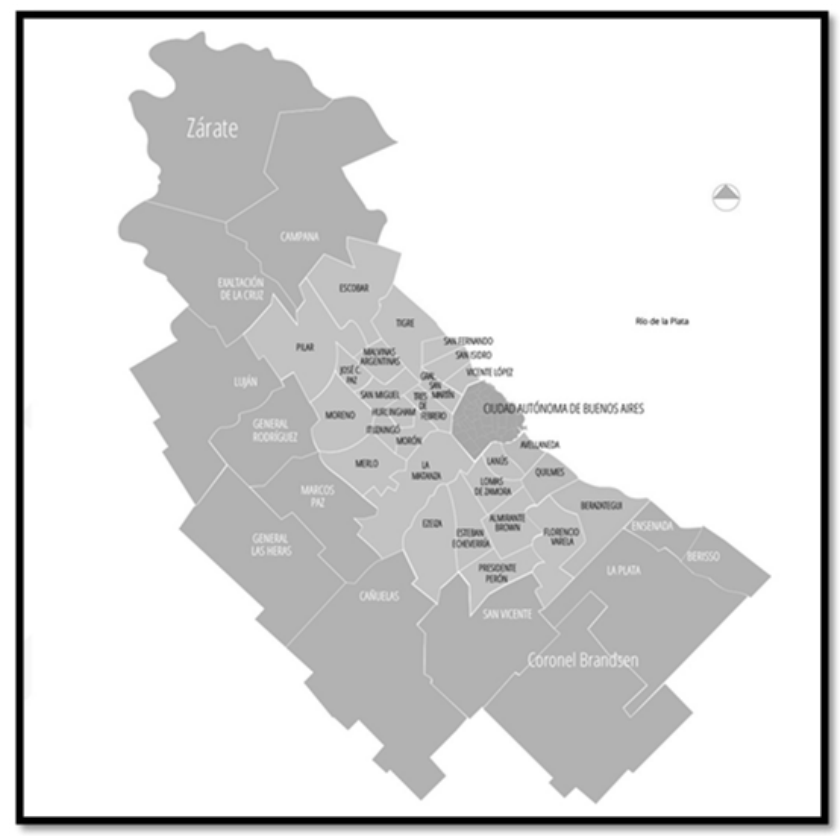

Figure I Metropolitan Area of Buenos Aires, 33 municipalities and the "conurbanados" cordons. Source: metropolitan observatory of the Professional Council of Architecture and Urbanism.

We mention the last characteristic because when the first generation of indigenous arrived to Buenos Aires, as a consequence of highly and repeated violence situations lived in the rural areas, one of the primarily acts was to not socialize the language, or other cultural expressions. This decision sought to reduce the experiences of discrimination and racism in the new context of reception. However, this conscious action is far from implying a process of cultural loss since the first years in Buenos Aires did not disable the conditions that shaped what Miguel Bartolomé ${ }^{10}$ defines as "clandestine identity". ${ }^{2}, 10$ That is to say, although we are not going to specifically

${ }^{2}$ The author asks how it was that for decades different ethnocultural collectivities remained invisible. Part of this was possible thanks to the ontological blindness of both anthropology and society, as well as the creation of a "clandestine identity" by social groups whose ethnic stigmatization induced them to develop a "culture of resistance". ${ }^{11}$ 
refer on that, it is important to mention the relevance that during the 1960s and 1970s certain spaces of ethno-political participation in the peripheral neighborhoods of the AMBA and the Autonomous City of Buenos Aires had in relation to analyze the collective experiences of organization of the migrant indigenous population. ${ }^{3}$ These experiences of ethno-political participation, while defines the second aspect, are important to emphasize how brought an increase of the socialization and communication between the newly arrived indigenous families; which gradually constituted various instances of discussion of rights based on a greater ethnic awareness, especially after the end of the last military dictatorship of our country (1976-1983). ${ }^{4}$ According to that, the transition towards the recovery of democracy and its impact on state structures shaped new relations between the State and civil society, where a new layer of indigenous leaders formed in Buenos Aires and in other regions of the country participated. As a main characteristic of these relationships we can highlight that these new leaders socialize their claims into a context constituted by different social sectors, labor experiences, union and militancy spaces highly differentiated from those past times where welfare and paternalistic relations where more common. ${ }^{15}$

So far, we have highlighted two main aspects. The first one was the importance that the migration process has in the analysis of indigenous populations to counteract those positions that assume their presence as a contemporary phenomenon. And the second one, we mention the increase in ethnic awareness of the late 1960s has been expressed through the formation of ethno-political spaces and participation in Buenos Aires and in other regions of the country. Both allow understanding historically those conditions that enabled the recent processes of organization of the urban indigenous population and help us to understand at least the last two remaining points. That is and in third place, the impact that the recognition of rights and the reform of the National Constitution of 1994 had in the modalities of participation, organization and indigenous negotiation. And finally, the fourth and last point refers to analyze the process by how the forms of institutional organization of indigenous ethno-political practice in Buenos Aires -from the end of 1990 onwards- take an institutionalized course. Nevertheless, before describing both aspects, it is important to characterize the indigenous population settled in the AMBA.

As we have pointed out, it was during the 1960s that the first indigenous families arrived at the AMBA. Most of them became from the region of $\mathrm{Chaco}^{5}$ and settled into the news spaces thanks to the

${ }^{3}$ The migrant indigenous population in Buenos Aires, ethnically and ideologically heterogeneous, was generating some foci of meeting around cultural events, in Associations and clubs coprovincianos. These outbreaks were gradually and organizationally unsuccessful, and the emergence of an ethnic ideology without clear profiles that claimed a generic indigenous ethnicity historically disqualified by the process of colonization and domination and which was reborn in relation to the Rescue of the cultural values of each ethnic group in particular and of the whole of the Argentine indigenous population in general. ${ }^{12}$ Thus, the participants of these meetings form the Indigenous Center of Buenos Aires, and a group of them focuses on the need to link with their communities of origin to initiate a process of "rescue of Aboriginal cultures". ${ }^{12}$ These aims will make the Center to become the Coordinating Commission of Indigenous Institutions of Argentina (CCIIRA), whose objective was to revitalize the ethnic conscience of the aboriginal population and to contribute to the different demands that it had. ${ }^{10,12-14}$ Finally, the Indigenous Association of the Argentine Republic (AIRA) was created in 1975.

${ }^{4}$ The National Reorganization Process, also known as the last civic-military dictatorship, is the name with which the military dictatorship that governed Argentina was called since the coup d'etat of March 24, 1976, when the constitutional government was overthrown of the president María Estela Martínez de Perón.

${ }^{5}$ Being one of the geographical regions of our country its natural limits are defined by the Pilcomayo river to the north, the Paraguay and Paraná Rivers networks of relatives in various neighborhoods located in the south of the Autonomous City of Buenos Aires, Avellaneda and Dock Sud (southern zone of the AMBA). The indigenous population settle in the AMBA are Tupí-Guaraní, Avá-Guaraní from the "Chaco salteño" or Kollas and Diaguitas-Calchaquíes from the province of Jujuy. In addition, Toba/Qom and Mocovíes families migrate from the province of the Chaco and in smaller amount there are Mapuches families from the center of the country and the Patagonian region. At first glance, this diversity of identity indicates a differentiation of experiences of origin, motives and causes of migration as well as a complex cultural history that is concentrated in Buenos Aires. Thus, the heterogeneous interethnic composition of the urban indigenous population is matched by a range of forms of organization that cannot be reduced to the category of the "urban indigenous".

According to the data from the last National Population, Household and Household Census, the number of households with one or more indigenous people or descendants of indigenous peoples from the central region of the country (provinces of Córdoba, Santa $\mathrm{Fe}$ and Buenos Aires, the Interior or the province, CABA and AMBA) concentrated the $52.68 \%$. However, if we discriminate against CABA and AMBA from the other provinces of the entire region, we can say that just over a quarter of indigenous households (28.8\%) are concentrated in the AMBA. Finally, the regions PampeanaPatagónica, Northwest and Northeast, concentrate 17.6\%, 14.4\% and $6.5 \%$ and the ones with the lowest incidence in the total of the country the region are Cuyo with 5.7\% and Mesopotamia with 3.1\%. ${ }^{16}$ This kind of census information is more detailed in the following Table 1.

As we can see, the high percentage of indigenous population in the central region of the country indicates the high concentration of industry and the sector of services that the region offers in terms of the labor market. But also, it's the clear expression of a migratory tendency that accompanied the urbanization process of the periphery of CABA, where indigenous population became protagonist of that. In this way, the presence and visibility that the indigenous population acquired in recent years and specifically in the urban context, through the recognition of their rights is not the expression of a casual or new phenomenon. Below, we will mention those legislations that intervened in the indigenous population ethno-political organization process and emphasize how the legislative achievements form previous stages marked the increase of political and institutional participation into the structure of the State. That process characterized the third aspect to highlight: the legal recognition of the indigenous population in Argentina.

One of the main achievements of the 1980s was the enactment of the Law $23.302^{6}$ named "Indigenous Policy and Support to Aboriginal Communities" of 1985. Although its regulation happened three years after its sanction, one of its results was the creation of the National Institute of Indigenous Affairs (INAI) as a public and specific

to the east, the Salado River to the south and the North region to the west. In turn it is divided into the central zone characterized by a more clayey soil, the formation of marshes and bathed and the eastern zone that has higher levels of humidity with formations of forest. This region exceeds the limits of Argentina since it includes the southeast of Bolivia and Paraguay and the southwest of Brazil.

${ }^{6}$ It is during the First National Indigenous Parliament (Neuquén) in 1972 that the different guidelines on legal aspects that give rise to the draft bill $23,302^{14,17}$ are drawn up. Both the Neuquina Indigenous Confederation and the Coordinating Commission of Indigenous Institutions of Argentina organized the event. Andrés Serbín marks the realization of the official initiative as an important action insofar as it opened up the possibilities of an alternative and public indigenous project, independently of the electoral context of the Neuquén governor (1981). 
institution for the implementation of indigenous policy. ${ }^{15}$ We should also be mentioned that in the 1990s, after its creation and because of injection of state resources, the INAI marked a new platform of participation and consultation of indigenous populations in our country. In this line and as a result of the struggles of the past decades, in 1994 the National Constitution was reformed and the indigenous population became a subject of law thanks to the Article $\mathrm{N}^{\circ} 75$, inc. 17 , which allows: "To recognize the ethnic and cultural pre-existence of the indigenous peoples of Argentina. Ensure respect for their identity and the right to bilingual and intercultural education; Recognize the legal status of their communities and the communal ownership and ownership of the lands they traditionally occupy; And regulate the delivery of other suitable and sufficient for human development; None of them shall be transferable, transferable, or subject to encumbrances or liens. Ensure their participation in the management of their natural resources and the other interests that affect them. The provinces can concurrently exercise these powers ". 18

Table I Households by region with one or more indigenous people or descendants of indigenous peoples over total households by region. ${ }^{21}$

\begin{tabular}{|c|c|c|c|}
\hline \multirow[t]{2}{*}{ Region } & \multirow[t]{2}{*}{$\begin{array}{l}\text { Total households by } \\
\text { region }\end{array}$} & \multicolumn{2}{|c|}{$\begin{array}{l}\text { Households by region with one or more } \\
\text { indigenous person's descending of "pueblos } \\
\text { originarios" }\end{array}$} \\
\hline & & Number & $\begin{array}{l}\text { Percent on the total of households } \\
\text { per region }\end{array}$ \\
\hline Pampeana-Patagónica Region & 754.838 & 64.848 & $8,59 \%$ \\
\hline Noroeste Region & 1.030 .060 & 53.283 & $5,17 \%$ \\
\hline Noreste Region & 646.75 & 23.987 & $3,70 \%$ \\
\hline Cuyo Region & 798.918 & 20.987 & $2,62 \%$ \\
\hline Centro Region (total) & 7.995 .238 & 194.324 & $2,43 \%$ \\
\hline A. Autonomous city of Buenos Aires & I.150.134 & 32.294 & $2,80 \%$ \\
\hline B. Grater Buenos Aires & 2.934 .373 & 73.879 & $2,51 \%$ \\
\hline $\begin{array}{l}\text { C. Rest of the central Region (excluding Grater } \\
\text { Buenos Aires and the Autonomous city of Buenos } \\
\text { Aires) }\end{array}$ & 3.910 .731 & 88.151 & $2,25 \%$ \\
\hline Mesopotamia Region & 945.871 & 11.464 & $1,21 \%$ \\
\hline Total & 12.171 .675 & 368.893 & $3,03 \%$ \\
\hline
\end{tabular}

After the reform, the indigenous population becomes a "legal subject". Among the legal arrogations granted, in our case we highlight the impact of the recognition of the indigenous legal status, the possibility to delivery lands suitable for their development and the notion of participation that refers to the management of specific interests. Mentioning the latter, we can describe the fourth aspect that refers to the increase in the number of indigenous legal entities in the recent years and also named as "comunidades indígenas". According to that, we want to point out how this process brought to the increase and more institutionalized ethno-political practice. Although we understand that the access to the recognition -as a "comunidad indígena" to the State- implies more possibilities for receiving and managing state resources; it also implies differential dynamics that transforms the ethno-political practice and its legitimation in the contemporary leaderships. As for the positive results of those who have the recognition, we can mention the use of resources destined to implement social programs in the communities or projects to strengthen the identity in the urban area, the language or the culture. However, resource management not only stresses the leaders who distribute them to the community members, also has effects in the dynamics that the State recognition establishes between those communities recognized from the non-recognized ones. That situation establishes an arena of high conflict levels between the communities and the interethnic and intercultural spaces. Likewise, the redefinition of the relationship with the State regarding the recognition and management of public resources will signify the collectivization of demands in an ethno-political field with specifically ethnic objectives and claims. This situation of greater organization and visibilisation can be found in the following graph that shows the increase in number of indigenous communities recognized by the Argentine State in the province of Buenos Aires (Table 2).

Table 2 It shows the amount of the Indigenous Communities registered in the National Register of Indigenous Communities (Re.Na.Ci.) in the province of Buenos Aires until 2012.

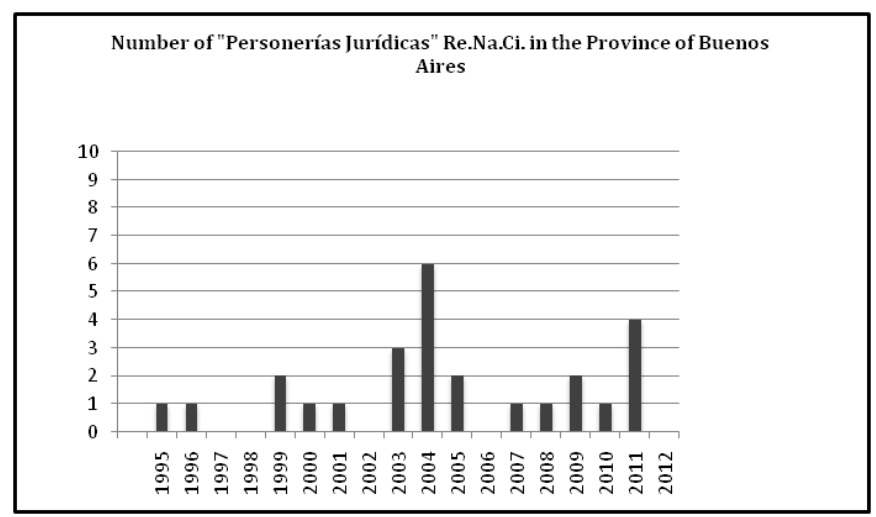

On the other hand, if the recognition of the 26 communities registered in the province of Buenos Aires is contextualized during the mid-1990s, we can justify that this increase was partly a response 
to the negative impact of state privatization, the structural adjustment and the fiscal discipline on the sectors of more vulnerability. As "in urban conglomerates, the unemployment rate increased from $2.4 \%$ in April 1975 to $20.2 \%$ in May 1995, while the underemployment rate rose from 4.7\% in April 1975 to $12,6 \%$ in May $1996 .{ }^{19}$ Although we understand the growth in number of the legal entities as an absolute variable, its increase corresponds to a situation where the fifth of the population of the AMBA was unemployed.

So, it should be mentioned that the increase of "indigenous communities" in the province of Buenos Aires is not a direct consequence of the high levels of poverty and unemployment, because it also expresses a trend of greater collective organization of the indigenous population. In this line Carolina Maidana points out that there is a constant dynamic of gestation, conformation and/ or division of the indigenous nucleations in a context characterized by client relations and leadership disputes where neighborhood commissions, cooperatives and civil associations are structured. So the number of registered "communities" in official figures would only account for a portion of the reality. The centrality that the State and its dependencies occupy in the last years, after the recognition, becomes a key to address the analysis of the demands and how they affect the ethno-political organization of the indigenous population of the AMBA. For example, the formalization of the indigenous families in the municipality of Almirante Brown was characterized by a high level of conflict between the different nucleations. That was expressed when a sector of the Tupí-Guarani "Cacique Hipólito Yumbay" extended family was split by a conflict related to the management of resources, reason why they decided to initiate the process for its own State recognition. As a result, the "Cuimbae Toro" community was the last to be recognized on May 19, 2011 by the Resolution N $\mathrm{N}^{\circ} 241$ of the INAI. On the other hand, other local communities such as "Juan Kalfulkurá", "Nogoyin Ni Nala "and" Cacique Catán "presented the documentation for their recognition, which is still in process. The table below details the recognized and non-recognized communities of the indigenous population of Almirante Brown (Table 3).

Table 3 Indigenous communities of Almirante Brown with and without Legal Personería Re.Na.Ci

\begin{tabular}{ll}
\hline Communitie name & Personería jurídica Re.Na.Ci. - inai \\
\hline Tupí-Guaraní “Cacique Hipólito Yumbay” & Has from 1999 \\
Toba “Migtagan” & Has from 2000 \\
Kolla “Guaguajni Jallpa” & Has from 2008 \\
Avá-Guaraní “Cuimbae Toro” & Has from 20II \\
Toba-Mocoví “Nogoyin Ni Nala” & Don't have - It's in process \\
Mocoví “Cacique Catán” & Don't have - It's in process \\
Mapuche "Juan Kalfulkurá” & Don't have - It's in process \\
\hline
\end{tabular}

Finally, the constitution of ethno-political spaces of participation must be understood according to the institutionalizing platform acquired by the new generations of "urban indigenous people" and their leaders. As we have seen, the macro-political, legal and economic contexts put in movement processes through where the indigenous population of the AMBA carried out different forms of articulation and outlined strategies to negotiate both indigenous rights recognized by the Argentine State and to improve their urban living conditions. This new field of struggles not only introduces intercultural alliances between indigenous, public workers and other social actors. It also shows how the "urban indigenous" acquired administrative and bureaucratic knowledge through the process recognition by the State and thanks to the management of public resources of the last ten years. This platform can also show us how the cultural transfiguration ${ }^{8}$ takes place in a negotiation of "indigenous emergency". We mean that ethnicity today; although it is the expression of the political action ${ }^{11}$ doesn't look only for the autonomy of the indigenous people. Now at days, we must think ethnicity as part of both claims: the recognition of the cultural identity in the state participation. In other words, ethnic and civil rights aren't opposite poles into the indigenous contemporary struggles.

As an example, the indigenous communities of Almirante Brown in 2008 form part of the local government structure. Their ethno-political organization articulated with some of the political representatives where the platform to make an agreement. From that political conquest was created the "Coordinación de Pueblos

Originarios de Almirante Brown”. This space represents in words of some of the local indigenous leaders, the expression of their voice as citizens. According to the ethnographic work, the principal claims not only were those about the territorial issues and cultural rights, but also they ask the improved of their living conditions, education, housing, work and health.

\section{Conclusion}

We have analyzed the conditions and the process where the indigenous population of the AMBA carried out greater ethnopolitical instances of organization, participation and recognition of violated rights. In this regard, we have considered that the formation and organization of the indigenous migrant population must be done from an approached according to four thematic aspects. The first one is to emphasize how migratory process, from certain historical depth, are articulated by relations of relatives, alliances and related in the AMBA and CABA. This discusses the fact that assume indigenous people as part of the rural context in general and the negation as part of the population in Buenos Aires in particular. Secondly, we show the increase, since the end of $1960 \mathrm{~s}$, of an ethnic awareness that allowed the socialization of the new leaderships beyond welfare and paternalistic ties. In third place, the institutional recognition of the 1994 year and the subsequent creation of participation agencies in the structure of the State generated the tools for increase the organization of the indigenous people in the urban areas of AMBA and CABA. And, finally, the formalization of the "communities" increase the autonomy and the management of state resources. 
As a conclusion and far from presenting the process from a supposed state of "gradualism" or equilibrium, we mentioned that this process was characterized by high levels of conflict. Nevertheless, we considerer that the process of ethno-political organization has made a qualitative leap, since the socialization of the new indigenous leaderships in the city have stimulated the need to create instances of local organization for the indigenous population and the formalization of spaces for participation in the local governments of the AMBA. ${ }^{20,21}$

\section{Acknowledgements}

None.

\section{Conflict of interest}

Author declares that there is no conflict of interest.

\section{References}

1. Engelman JY, Weiss ML. El imán de la ciudad: migración y distribución espacial de población indígena en el Área Metropolitana de Buenos Aires, Argentina. Revista Geopantanal. 2015;18:51-70.

2. Tamagno L. Indígenas en la ciudad. Organización política en contextos de tensión entre patrimonio cultural y políticas públicas. In: Tamagno L \& Maffia M, editors. Indígenas, africanos y afrodescendientes en la Argentina, Convergencias, divergencias y desafíos, Argentina; 2014. p. 43-62.

3. INDEC. Censo Nacional de Población, Hogares y Viviendas 2010-Censo del Bicentenario. Pueblos Originarios, Región Metropolitano. 2015;6:1-49.

4. Bartolomé M. La diversidad de las diversidades. Reflexiones sobre el pluralism cultural en América Latina. Cuadernos de Antropología Social. 2008;28:33-49.

5. Trinchero H. Los pueblos originrios en la formación de la Nación Argentina. Revista Espacios. 2010;46:106-123.

6. Balazote A. Pueblos Originarios: disputas en el campo discursivo. Universidad de Brasil. 2015;18(10):33-50.

7. Ratier H. Villeros y Villas Miserias. Centro Editor de América Latina, Argentina; 1975.

8. Amodio E. Los indios metropolitanos: Identidad étnica, estrategias políticas y globalización entre los pueblos indígenas de América latina. In: Daniel M, Emanuele A, editors. América Latina en tiempos de globalización: Procesos culturales y transformaciones sociopolíticas, Venezuela; 1996. p. 51-66.
9. Tamagno L. Nam Qom Hueta 'a Na dockshi Lma: Los tobas en la casa del hombre blanco. Identidad, memoria y utopía. Argentina; 2001.

10. Bartolomé M. Los pobladores del Desierto genocidio, etnocidio y etnogénesis en la Argentina. Cuadernos de Antropología Social. 2003;17:162-189.

11. Bartolomé M. Gente de costumbre y gente de razón. Las identidades étnicas en México, Siglo 21. México; 1997.

12. Serbín A. Las Organizaciones Indígenas en la Argentina. Revista América Indígena. 1981;3(41):407-434.

13. Gordillo G, Hirch S. Movilizaciones indígenas e identidades en disputa en la Argentina. Revista Colombiana de Antropología. 2010;49(1):285.

14. Radovich JC. Política Indígena y movimientos etnopolíticos en la Argentina contemporánea. Una aproximación desde la Antropología Social. Revista Antropologías del Sur. 2014;1:133-145.

15. Radovich JC. Del paternalismo a la autogestión. Transformaciones en la política indígena en la Argentina. In: Radovich JC, Balazote A, editors. Estudios antropológicos sobre la cuestión indígena en la Argentina, Argentina; 1999. p. 13-24.

16. Weiss ML, Engelman J, Valverde S. Pueblos Indígenas Urbanos en Argentina: un estado de la cuestión”. Revista Pilquen. 2013;16(1).

17. Maidana C. Migrantes Toba (Qom). Procesos de Territorialización y construcción de identidades. Universidad Nacional de la Plata, Argentina; 2011.

18. Constitución Nacional Comentada por el Departamento de Derecho Público. Editorial Estudio SA, Argentina.

19. Manzano V. La política en movimiento. Movilizaciones colectivas y políticas estatales en la vida del Gran Buenos Aires, Argentina; 2013.

20. Engelman J. Migración étnica y condiciones de vida urbana al sur del Área Metropolitana de Buenos Aires. Revista Alteridades. 2016;26(52):67-79.

21. INDEC. Censo Nacional de Población, Hogares y Viviendas 2010. Censo del Bicentenario. Resultados Definitivos, Serie B N², Argentina:Tomo I; 2012. 